\title{
Публицистика об эмансипации женщин в 1920-1930 гг:: идеи, их реализация и судьбы феминисток
}

Ольга Минаева

В статье рассматривается концепция эмансипации советских женщин, разработанная в трудах

марксистских феминисток и реализованная в системе печати для женщин в 1920-1930 гг. Организаторами пропаганды в печати новых гендерных представлений и ведущими публицистами по «женскому вопросу» были деятельницы отдела по работе среди женщин ЦК ВКП(б) (Женотдела).

Ключевые слова: история России, история советской печати, Женотдел ЦК ВКП(б), советская печать для женщин.

DOI: 10.30547/mediaalmanah.5.2020.8492
(С) Минаева Ольга Дмитриевна доктор филологических наук, зав. кафедрой истории и правового регулирования отечественных СМИ факультета журналистики МГУ имени М.В. Ломоносова (г. Москва, Россия), olg-minaeva@yandex.ru
Эмансипация женщин была одной из важнейших социальных реформ советского периода, проходившая при участии государства, непосредственном руководстве со стороны ЦК ВПК(б) и значительном вкладе созданной в 1920-1930 гг. системы печати для женщин.

Деятельницы Женотдела были убежденными марксистками и, разделяя идеи феминизма, хотели достичь эмансипации женщин одновременно с другими социальными реформами в процессе построения нового строя. Поэтому многие исследователи рассматривают их как "марксистских феминисток» и представляется, что это точный термин.

Исследования истории журналов для женщин практически не велись в советское время, а за последние десятилетия были сделаны два серьезных исследования (Коломийцева, 2008; Смеюха, 2012) по типологии женской прессы за все три века истории российской журналистики. Советским журналам в них уделено немного внимания. Гораздо больше историками, социологами, культурологами изучается так называемый "женский вопрос», но не в ракурсе содержания прессы для женщин. Из работ по истории отечественного феминизма нужно отметить книгу Р. Стайтса (2004). Зарубежных исследователей привлекают 
труды А.М. Коллонтай с ее борьбой за свободу личности женщины.

\section{Система печати для женщин под руководством Женотдела ЦК ВПК(б)}

В сентябре 1919 г. в структуре ЦК партии большевиков был создан Отдел по работе среди женщин - Женотдел ЦК ВКПб, в 1926 г. его преобразовали в Отдел по работе среди работниц и крестьянок. Женотделу ЦК партии подчинялись республиканские, краевые, областные и районные женотделы.

В создании Женотдела ЦК ВКП(б) значительную роль сыграла И.Ф. Арманд, после ее смерти в 1920 г. отдел возглавила А.М. Коллонтай. После ее ухода на дипломатическую работу заведующей Женотделом стала С. Н. Смидович (1922-1924 гг.), затем К.И. Николаева (1924-1926 гг.) и А.В. Артюхина (1926-1930 гг.). Все они - убежденные большевички с дореволюционным опытом подпольной партийной работы. Длительное время заведующие Женотделом ЦК возглавляли журналы «Работница» и «Крестьянка».

«В 1918 г. партия только нащупывает методы работы. Периодической печати нет [имеется в виду женская печать. - O.M.] <...> В 1920 г. работа разворачивается: выработаны организационные формы, и появляется наша периодическая печать» 1 , - писала в 1925 г. Л. Сталь. В 1917-1941 гг. насчитывалось 97 газет и журналов для женщин. Сначала это были преимущественно газеты, но после окончания гражданской войны основным типом женского издания становится журнал. В 1920 г. тиражом 20 тыс. экз. был выпущен первый номер журнала "Коммунистка», предназначенного для партийных работников и агитаторов. В «Коммунистке» печатались статьи и дискуссии по спорным вопросам «раскрепощения» женщин, например о «свободной любви» или последствиях разводов. Журнал «Крестьянка» начал выходить в 1922 г. сначала как «информационный материал» для местных агитаторов с приложением
«Долой неграмотность»3. Затем, учитывая отсутствие «популярной литературы для крестьянок», с июня 1922 г. Женотдел ЦК изменил его формат на полноценный массовый журнал, тираж поднялся с 5 тыс. до 15 тыс. эк3.. В 1923 г. вновь начал выходить журнал «Работница», который пытались издавать в 1914 г. и в 1917 г.

В других сегментах системы партийносоветских СМИ публикаций по «женскому вопросу» было немного. Это происходило по разным причинам - недостаток кадров, отношение к этим темам как к второстепенным, несогласие с трактовкой вопросов равноправия женщин и т.д. Именно поэтому Женотделу ЦК удавалось на протяжении 1920 гг. мотивировать необходимость количественного роста печати для женщин.

В январе 1930 г. Женотдел ЦК ВКП(б) был упразднен, т.к. партийные руководители сочли «женский вопрос» в СССР окончательно решенным. Был закрыт и руководящий журнал «Коммунистка», так как исчезала его целевая аудитория - сотрудники местных женотделов, закрыт и журнал «Делегатка», который издавался женотделом Московского городского комитета (МГК) ВКП(б).

Стоял вопрос о том, нужно ли вообще оставлять женскую прессу. «Мы со всей категоричностью заявляем, что еще не настало время для ликвидации женских изданий»5, - заявляла Н. Торская в 1930 г. Она мотивировала это тем, что тираж массовых женских изданий достиг 800 тыс. экз., (не менее 2 млн читательниц), а «общая печать» не сможет соответствовать специфическим запросам и нуждам этой аудитории, «выдерживать тот необходимый уровень популярности», который ей нужен.

В 1935 г. выходило 19 женских журналов, в 1941 г. накануне войны их было 16 (центральные и республиканские). Журналы «Работница» и "Крестьянка», активно боролись за увеличение своих тиражей. В годы второй пятилетки работниц было около 7 млн, а тираж «Работницы» не удавалось поднять выше 400 тыс. экз. Аудитория 
«Крестьянки» была значительно больше, но тираж журнала в предвоенный период не превышал 300 тыс. экз.

Говоря современным языком, включение в повестку дня СМИ «женского вопроса» и работа по созданию системы печати для женщин - целиком заслуга Женотдела ЦК. За агитационными кампаниями и целенаправленной пропагандой идей эмансипации женщин в массовых женских изданиях не очень заметна глобальная цель - изменение гендерных стереотипов общества. Хотя именно на нее и были направлены в конечном счете все усилия Женотдела.

\section{Идеология эмансипации женщин}

Идеологами социал-демократического направления в феминистском движении России были в первую очередь А.М. Коллонтай и Н.К. Крупская. Они имели дореволюционный опыт пропагандистской работы, в том числе и в рамках феминистского движения, и во многом сформировали политику советского правительства по эмансипации женщин.

А.М. Коллонтай была народным комиссаром государственного призрения (соцобеспечения) в советском правительстве с ноября 1917 г. по март 1918 г., откуда ушла в знак протеста против заключения Брестского мира. Именно благодаря ее деятельности на этом посту был упрощен развод, улучшены условия труда женщин, узаконен декретный отпуск. А.М. Коллонтай разработала проект охраны материнства и младенчества, реализовать который ей частично удалось на посту наркома. Она предусмотрела оплату декретного отпуска, специальные дома для беременных и матерей, охрану труда беременной и кормящей матери и т.д.

Н.К. Крупская, будучи заместителем наркома просвещения РСФСР, сыграла важную роль в создании советской системы образования. Везде в центре ее внимания помимо "детских» вопросов была работа с женщинами, которые по сравнению с мужчинами были более угнетенными и малограмотными.

Все части концепции эмансипации женщин, разработанной марксистскими феминистками, логично связаны и отвечают на основные вопросы реформы жизни женщин и советского общества в целом. Они разработаны на основе марксистских убеждений феминисток, которые не уставали повторять, что интересы женщин тесно связаны с другими (общими) реформами, и поэтому женщины должны активно поддержать борьбу за улучшение жизни всего народа.

Основой взглядов, как Крупской, так и Арманд, Сталь, Коллонтай и других, был принцип полной экономической независимости женщины. «Все это, т.е. самостоятельная работа и самостоятельный заработок женщины, не могло не отразиться на отношениях между мужем и женой. Жена перестает быть рабой мужа, а делается равноправным членом семьи», - писала Крупская в книге «Женщина-работница»6.

Напрямую связана с трудовой деятельностью женщин идея Крупской о совместном и равном обучении мальчиков и девочек в школе. «Школа - место, где дети учатся работать $\langle. .$.$\rangle а работа ведь осно-$ ва жизни, - мы с первых же шагов должны развивать в них навык к совместной работе»7, - отмечала она в статье «Совместное обучение» в журнале «Русская школа» еще в 1911 г. Девочки должны иметь такой же доступ, как и мальчики, к образованию (от начального до высшего), причем обязательно получать трудовые навыки. Любые отступления от этого принципа поставят женщин в неравные условия на рынке труда и в браке.

Коммунисты считали, что семья, которая нужна была для решения бытовых проблем и воспитания детей, будет трансформирована или ликвидирована при коммунизме. Всероссийский съезд работниц в ноябре 1918 г. констатировал, что «семья перестает быть нужной для общества, так как с победой коммунизма все хозяйственные 
работы и заботы о членах семьи берет на себя коллектив, само государство трудящихся. Все материальные основы семьи исчезают. Брак превращается в свободный товарищеский союз двух равноправных, самостоятельно зарабатывающих членов великой трудовой семьи, <...> коллективное хозяйство должно заменить домашнее хозяйство и раскрепостить работницу как хозяйку. Воспитание и содержание детей на средства правительства (в яслях, детских садах, колониях и т.д.) должно снять материальную заботу о ребенке с отца и матери»8. По сути, это манифест женской партийной печати 1920 гг. Понятно, что резолюции съезда составляли Коллонтай и Арманд, а не работницы.

Н.К. Крупская писала: «Надо, чтобы государство <...> не только бы заботилось о женщине во время беременности, во время и после родов, но необходимо, чтобы государство создало десятки тысяч яслей, детских садов, детских колоний, детских общежитий, где бы дети получали уход, пищу, где бы они жили, развивались, учились в условиях, в десять раз лучших, чем какие могла бы для них создать своими единоличными усилиями самая заботливая мать. Это облегчило бы женщине до чрезвычайности ее положение, поставило бы ее на деле в равные условия с мужчиной»9.

В статье "Война и деторождение» 10 , написанной в 1920 г., она обосновала необходимость легализовать аборты, обозначив практически все аспекты темы абортов: как социальные, так и медицинские, психологические. Право на то, чтобы решать, сколько детей и когда иметь, - наиболее существенное право женщины, особенно когда содержать и растить этих детей часто приходится именно матери. С тех пор, как Крупская затронула тему легализации абортов, прошел целый век, уже доступны для всех средства контрацепции, но тема актуальна и сегодня, причем новых аргументов и противники, и защитники абортов за прошедшие годы не придумали.
Очевидна связь между тем, как Крупская писала о детях и их роли в жизни матери и как развивала эту тему женская массовая печать: «возня с ребятами»11, «работница видит много горя сдетьми, много забот»12, «как помочь матери, гнущейся под тяжестью деторождения»13. Выбор лексики формирует негативное отношение: «возня», «делишки», «много горя» с детьми, «привязана». В продолжение этой темы можно найти и рассуждения о "домашнем рабстве» и «каторге».

В женской прессе 1920 гг. активно формировалось негативное отношение к традиционным семейным отношениям. И.Ф. Арманд назвала семейный уклад «последней крепостью старого строя, старого рабства», которую нужно разрушить ${ }^{14}$. Чаще всего избавлением от такой семьи становится развод.

В 1925 г. Женотдел ЦК ВКП(б) обсуждал 15 предложения в новый «Семейный кодекс». Это один из наиболее содержательных документов Фонда 17 РГАСПИ, посвященного работе Женотдела. С точки зрения интересов женщин обсуждалось, нужно ли упростить или усложнить развод, как обеспечить женщине возможность содержать детей в случае развода, как помочь вырастить детей в условиях бедности 1920 гг. и т.д. Этот документ приоткрывает нам практику работы Женотдела, глубокие знания его сотрудницами условий жизни женщин разных социальных слоев, понимание важности принимаемых решений и т.д.

А.М. Коллонтай в статье «Дорогу крылатому Эросу!» («Письмо трудящейся молодежи») высказала свои взгляды на то, чем, собственно, будет заменена семья в будущем. Коллонтай считала, что есть два вида любви. «Эрос бескрылый» - инстинкт воспроизводства, легко возникающее и быстро проходящее влечение пола, «противоречит интересам рабочего класса», так как это потакание похоти. Второй вид - «Эрос крылатый» - это любовь, сотканная из тончайшей сети всевозможных душевно-духовных 
эмоций. Далее Коллонтай рассуждала о сложности "крылатого Эроса», уравнивая в этих рассуждениях мужчин и женщин. Она приводила такие примеры: «одного женщина любит "верхами души”, с ним созвучны ее мысли, стремления, желания; к другому ее властно влечет сила телесного сродства. К одной женщине мужчина испытывает чувство бережливой нежности, заботливой жалости, в другой он находит поддержку и понимание лучших стремлений...»16. Публицист считает «важным с точки зрения пролетарской идеологии и желательным, чтобы чувства людей становились "многоструннее"»17. Этот вывод можно понять как призыв совмещать разные виды любви к разным партнерам одновременно, что, естественно, вызвало шквал критики.

Манифест Коллонтай состоял в утверждении равенства мужчины и женщины в социальных и межличностных отношениях. Важно избавиться от «буржуазного чувства собственности»: необходимо «равенство без мужского самодавления и рабского растворения своей личности в любви со стороны женщины; взаимное признание прав другого, без претензии владеть безраздельно сердцем и душой другого»18. В свете высказанных идей логичным кажется вывод Коллонтай о том, что традиционная семья перестанет быть нужной. А поэтому женщинам «самостоятельного труда» и «могущим самостоятельно воспитывать своих детей» нужно ответить на такой вопрос: есть ли необходимость «непременно жить в одной комнате с любимым мужчиной»? (Говряков, 2015: 69)

Любовь, по мнению Коллонтай, будет занимать подчиненное место в жизни женщины (как и мужчины), тогда как общественная и производственная деятельность - основное. Считая главным делом своей жизни «утверждение равноправности женщин», она назвала неудачей «непонимание» соратниками по партии ее идей «в постановке брачного вопроса»19.

\section{Судьбы революционерок- феминисток}

Как судьба марксистских феминисток влияла на их взгляды и есть ли связь между ними? Кто были деятельницы Женотдела ЦК?

Александра Михайловна Коллонтай родилась в 1872 г. в богатой семье генерала. Ее мать была уроженкой Финляндии. Александра получила отличное домашнее образование. После того, как сдала выпускные экзамены в гимназии, пробовала посещать курсы и лекции. Рано вышла замуж, через три года разошлась с мужем, а маленького сына поручила заботам своей семьи.

Поиски полезной деятельности логично привели А. Коллонтай в революционное движение. Считая себя недостаточно образованной, поехала изучать социальные и экономические науки в университет в Цюрих, потом в Англию - знакомиться с «рабочим движением». В результате Коллонтай, по ее собственному признанию, осознанно выбрала марксизм. Была хорошо знакома с деятелями немецкой социалдемократии, занималась журналистикой, работала агитатором социалистов в нескольких странах Европы. Член РСДРП, с 1915 г. состояла во фракции большевиков. В 1920-1923 гг. возглавляла Женотдел ЦК РКП(б), затем была послом СССР в Норвегии, Мексике, Швеции. В годы Второй мировой войны вела переговоры, которые привели к выходу из войны Финляндии. Умерла в 1952 г.

А.М. Коллонтай нравилось выступать агитатором, убеждать в правоте своих идей. Уже на закате жизни Александра Михайловна Коллонтай писала: «Тот энтузиазм, каким бывает "одержим" агитатор, проповедующий и борющийся за новую идею или положение, это душевное состояние сладко, близко к влюбленности. <...> Я сама горела, и мое горение передавалось слушателям. Я не доказывала, я увлекала их. Я уходила после митинга под гром рукоплесканий, шатаясь от усталости. Я дала 
аудитории частицу себя и была счастлива» (цит. по: Каравашкова, 1973: 48).

У статей А.М. Коллонтай сложный язык, они переполнены историческими примерами, научной лексикой. Такие понятия, как «сдвиг во всех областях жизни», «процесс исторического развития», «высокая производительность», «тысячелетия», «духовные скрепы», «брачный идеал» и т.д., вряд ли были знакомы малограмотной аудитории советской печати.

Коллонтай приписывали при жизни множество романов. В сорок пять лет она вышла замуж за двадцативосьмилетнего Павла Дыбенко - наркома по морским делам советского правительства, который происходил из бедной крестьянской семьи и едва умел читать. Этот брак продержался недолго, больше Александра Михайловна в брак не вступала. Собственно, ее жизнь полностью соответствовала ее взглядам. Она состоялась как личность и вошла в историю страны и эмансипации советских женщин. И в значительной степени судьба Коллонтай также сильно воздействовала на современниц, как и ее горячая пропаганда путей раскрепощения женщины.

Надежда Константиновна Крупская родилась в 1869 г. в дворянской, хотя и обедневшей семье. Окончила частную гимназию Оболенской, после смерти отца подрабатывала, давая уроки. Крупская вспоминала, что гувернантки и домашние учителя часто оказывались в унизительных ситуациях. Революционное движение было логичным выбором полезного поприща для Крупской. Во время ссылки в Сибирь вышла замужза В.И. Ульянова (Ленина). Вся дальнейшая жизнь Крупской связана с партией большевиков. После Октябрьской революции создание новой прогрессивной системы образования, борьба с неграмотностью и за эмансипацию женщин были основным делом Н.К. Крупской, умершей в 1939 г.

Из публицистов Женотдела именно Крупская была наиболее активна в пропаганде своих взглядов. Количество ее публикаций в центральных газетах за весь советский период - 798, в журналах - 734. Практически все темы, интересные для Крупской, взаимосвязаны: положение женщин, воспитание детей, вопросы школьного образования, быт, новые отношения в семье и т.д. Даже в статьях о библиотечном деле есть замечания о том, как книги формируют представления о гендерных ролях.

В публицистике мало проявилась ее личность. Исключением является лишь книга воспоминаний о Ленине: в ней Крупская человек и женщина - немного открывается миру. Она пишет с юмором, отмечает интересные детали их жизни. В отличие от Коллонтай Крупская была застенчива (и сама это признавала), не любила привлекать к себе внимание.

Работу пропагандиста Крупская считала своим партийным долгом, хотя не находила у себя литературных способностей и публицистом себя не считала. Идейное наследие Крупской значительное, а в ее публицистике содержание всегда гораздо интереснее и важнее, чем форма.

Инесса Федоровна Арманд родилась в 1874 г. в семье оперных певцов, знала несколько языков, была хорошо образована. В 19 лет вышла замуж за А.Е. Арманда, сына богатого купца. В двух браках у нее было пять детей, что не помешало ей вступить во фракцию большевиков, участвовать в подпольной работе и в революции 1905 г. в России. Она активно агитировала за раскрепощение женщин после Октябрьской революции и возглавила созданный в 1919 г. Женотдел. Умерла в 1920 г. от холеры.

Также как и Коллонтай, И.Ф. Арманд предпочла революционную романтику мирным будням матери семейства. И в значительной степени демонстрировала воплощение своих взглядов в реальной жизни.

Из дворянской семьи происходила и Софья Николаевна Смидович, в первом браке жена П.В. Луначарского, старшего брата А.В. Луначарского. Родилась в 1872 г. Получила хорошее домашнее образование. 
Член РСДРП с 1898 г. Второй муж - П.Г. Смидович, тоже социалист. В 1919-1922 гг. она возглавляла Женотдел Московского горкома партии, в 1922 г. - Женотдел ЦК РКП(б) вместо А.М. Коллонтай. Умерла в 1934 г.

В революционном движении участвовало много образованных женщин из дворянских и разночинных семей. Тюрьмы и ссылки, трудная жизнь подпольщиков, часто - разрыв с семьями и привычной средой влияли на характер и систему взглядов этих женщин. Не случайно у Людмилы Заславской была фамилия-псевдоним Сталь.

Людмила Николаевна Сталь (Заславская) родилась в 1872 г. в семье фабриканта. В социал-демократическом движении с 1890 г. После Октябрьской революции была сотрудником Женотдела ЦК РКП(б), заведовала отделом массовой литературы для работниц и крестьянок в Госиздате, одновременно с 1924 г. - редактор журнала «Коммунистка». Умерла в 1939 г.

Конкордия Николаевна Самойлова родилась в 1876 г. Из семьи священника, после окончания гимназии, как и Крупская, год проучилась на Бестужевских высших женских курсах. Затем участие в студенческом движении и революционная работа с арестами и ссылками. Была секретарем редакции «Правды» в 1912 г, в 1914 г. - участница выпуска первого номера «Работницы». В ноябре 1917 г. руководила первой конференцией работниц, была разъездным инструктором ЦК РКП (б) по работе среди женщин, работала в газете «Правда» и журнале «Коммунистка». Умерла в 1921 г. от холеры.

Клавдия Ивановна Николаева родилась в 1893 г. Работница переплетной мастерской, из рабочей семьи, училась в начальной школе и на курсах марксизма-ленинизма. В 1909 г. вступила в РСДРП. В 1917 г. входила в редколлегию журнала «Работница». Заведовала женотделом и агитпропотделом Петроградского губернского комитета РКП(б). В 1924-1926 гг. возглавляла Женотдел ЦК ВКП(б), в 1930-1933 гг. руководила агитмассовым отделом ЦК ВКП(б). С 1936 г. секретарь ВЦСПС. Умерла в 1944 г.

Александра Васильевна Артюхина из рабочей семьи, родилась в 1889 г., окончила начальную трехлетнюю школу, с 12 летработала ткачихой, потом на машиностроительном заводе. В 1910 г. вступила в РСДРП. В 1912-1914 гг. в «Правде» публиковались ее корреспонденции. С 1924 г. заместитель, в 1926-1930 гг. заведующая Женотделом ЦК ВКП(б). В 1924-1931 гг. - редактор журнала «Работница». Затем работала председателем профсоюза текстильных работников и директором ткацких фабрик. Умерла в 1969 г.

У нас мало сведений о сотрудниках «Работницы» и «Крестьянки», только в некрологах немного рассказывалось об их судьбах. Вот, например, что написали про Клавдию Георгиевну Иванову. До революции была ткачихой, с тремя детьми ушла от самодура-мужа. После Октябрьской революции девять лет работала в детских домах для беспризорных детей, в 1924 г. в Ленинский призыв вступила в партию. «Последние семь лет тов. Иванова заведовала сектором расследования журнала "Работница". Проявляла огромную любовь кделу, большую чуткость и внимательность к каждой жалобе, к каждому сигналу рабкорки <...> смело критикуя недочеты в работе невзирая на лица»20.

Различия в уровне образования, разные семейные истории и принадлежность к разным классам не препятствовала дружной и солидарной работе в Женотделе и в женских журналах женщин, прошедших тюрьмы и ссылки, подпольную работу, а главное - сознательно выбравших такую судьбу ради лучшей жизни для народа. Идеи эмансипации женщин, сформулированные марксистками-феминистками в самом общем виде, подробно и последовательно развиваются в женской прессе. Возможно, бывшие работницы несколько уравновешивали идеализм таких революционерок, как Коллонтай. 
Очевидно, что профессиональный уровень партийных женских журналов растет на протяжении всего довоенного периода. Но вопрос, как работницы с начальным образованием могли полноценно заниматься журналистикой, все же возникает.

\section{Выводы}

Отечественная партийная пресса для женщин содержала как агитационные лозунги, так и пропаганду целостного, мотивированного сценария того, как именно должна выстраиваться жизнь женщины через несколько лет или десятилетий. Этот сценарий был выстроен на основе идей, высказанных в публицистике Александрой Коллонтай и Надеждой Крупской. В начале 1920 гг. условия жизни и экономика страны не позволяли реализовать все идеи феминисток, но в 1960-1970 гг. именно их модель была успешно реализована.

Несмотря на некоторые «перегибы» и попытки быстро, не считаясь с условиями и гендерными стереотипами общества, реализовать свои, безусловно, прогрессивные идеи установления равноправия женщин, марксистки-феминистки обогнали свой век и обеспечили следующим поколениям советских женщин возможности для самореализации.

\section{Примечания}

${ }^{1}$ Сталь Л. Печать для работниц и крестьянок // Коммунистка. 1925. № 6. С. 44.

2 О деятельности отдела ЦК РКП по работе среди женщин // Коммунистка. 1920. № 5. С. 38.

з Отчет отдела ЦК РКП по работе среди женщин // Известия ЦК РКП(б). 1922. № 7. C. 31.

4 Отчет отдела ЦК по работе среди женщин // Известия ЦК РКП(б). 1923. № 3. С. 105.

5 Торская Н. Задачи массовой женской печати // Коммунистка. 1930. № 2-3. С. 11.

${ }^{6}$ Крупская Н.К. Педагогические сочинения: в 10 т. / под ред. Н.К. Гончарова, И.А. Каирова, Н.А. Константинова. М.: Изд-во Акад. пед. наук, 1957. Т. 1. С. 87.

7 Там же. С. 146.

8 Резолюция по вопросу “Семья и коммунистическое государство» // Коммунистическая партия и организация работниц: сб. статей, резолюций и конструкций: пособие для пропагандисток. М.: Коммунист, 1919. С. 120.

9 Крупская Н.К. Война и деторождением // Крупская Н.К. Педагогические сочинения: в 10 т. / под ред. Н.К. Гончарова, И.А. Каирова, Н.А. Константинова. М.: Изд-во Акад. пед. наук, 1959. Т. 6. С. 8.

10 Коммунистка. 1920. № 1-2.

${ }^{11}$ Крупская Н.К. Женщина-работница // Крупская Н.К. Педагогические сочинения: в 10 т. М.: Изд-во Акад. пед. наук, 1957. Т. 1. С. 75.

12 Там же. С. 94.

13 Крупская Н.К. Война и деторождение // Крупская Н.К. Педагогические сочинения: в 10 т. М.: Изд-во Акад. пед. наук, 1959. Т. 6. С. 8.

14 Блонина Е. Освобождение от домашнего рабства // Коммунистическая партия и организация работниц. С. 33.

15 Стенограмма совещания отдела работниц с выступлением А.М. Коллонтай. 2 января 1925 г. // РГАСПИ. Ф. 17. Оп. 10. Д. 140 А. 71 л. 
16 Коллонтай А.М. «Дорогу крылатому Эросу!» // Молодая гвардия. 1923. № 3. С. 76.

17 Там же. С. 77.

18 Там же. С. 85.

19 Коллонтай А.М. Летопись моей жизни. М.: Academia, 2004. С. 267-269.

20 Прощай, дорогой товарищ! // Работница. 1938. № 2. С. 17.

\section{Библиография}

Говряков И.Ю. Каким быть социалистическому городу: проекты реформирования быта и советская женщина 1920-х гг. // МедиаАльманах. 2015. № 1. С. 67-72.

Каравашкова С.В. Публицистика А.М. Коллонтай, И.Ф. Арманд, Л.Н. Сталь, А.И. Ульяновой-Елизаровой в борьбе за укрепление международного рабочего движения. М.: Изд-во Моск. ун-та, 1973.

Коломийцева Е.Ю. Формирование женского универсального журнала в отечественной журналистике XVIII-XX веков: дис. ... д-ра филол. наук. Армавир, 2008.

Смеюха В.В. Феномен гендерной идентификации в медийном пространстве (на материале отечественных женских журналов): дис. ... д-ра филол. наук. Краснодар, 2012.

Стайтс Р. Женское освободительное движение в России: Феминизм, нигилизм и большевизм, 1860-1930. М.: РОССПЭН, 2004. 